\title{
Inactivation of Myelin-Associated Glycoprotein Enhances Optic Nerve Regeneration
}

\author{
Eric V. Wong, ${ }^{1,3}$ Samuel David, ${ }^{2}$ Michele H. Jacob, ${ }^{1}$ and Daniel G. Jay ${ }^{1}$ \\ ${ }^{1}$ Departments of Physiology and Neuroscience, Tufts University Medical School, Boston, Massachusetts 02111, ${ }^{2}$ Center for Research in Neuroscience, \\ Montreal General Hospital Research Institute and McGill University, Montreal, Quebec, Canada, and ${ }^{3}$ Department of Biology, University of Louisville, \\ Louisville Kentucky 40292
}

CNS regeneration in higher vertebrates is a long sought after goal in neuroscience. The lack of regeneration is attributable in part to inhibitory factors found in myelin (Caroni and Schwab, 1988a). Myelin-associated glycoprotein (MAG) is an abundant myelin protein that inhibits neurite outgrowth in vitro (McKerracher et al., 1994; Mukhopadhyay et al., 1994), but its role in regeneration remains controversial. To address this role, we performed nerve crush on embryonic day 15 chick retina-optic nerve explants and then acutely eliminated MAG function along the nerve using chromophore-assisted laser inactivation (CALI). CALI of MAG permitted significant regrowth of retinal axons past the site of lesion containing CNS myelin in contrast to various control treatments. Electron microscopy of the site of nerve crush shows abundant regenerating axons crossing the gap. When crushed optic nerve was retrogradely labeled at the nerve stump, no labeling of retinal neurons was observed. In contrast, labeling of CALI of MAG-treated crushed optic nerve showed significant retinal labeling ( $89 \pm 16$ cells per square millimeter), a value indistinguishable from that seen with non-crushed nerve ( $98 \pm$ 13 cells per square millimeter). These findings implicate MAG as an important component of the myelin-derived inhibition of nerve regeneration. The acute loss of MAG function can promote significant axon growth across a site of CNS nerve damage.

Key words: MAG; CALI; optic nerve explants; nerve regeneration; retinal neurons; myelin

\section{Introduction}

Long-distance axonal regeneration in the CNS does not occur in adults of higher order vertebrates. This is thought to be attributable to a reduced intrinsic ability of adult neurons to sprout neurites and to inhibition by the environment, particularly the CNS myelin. CNS (but not PNS) myelin inhibits nerve regeneration (Caroni and Schwab, 1988a), and lesioned CNS neurons can grow along PNS nerve grafts (David and Aguayo, 1981). The search for inhibitory proteins in CNS myelin has yielded a number of candidate molecules. The first inhibitory activity was detected by the monoclonal antibody IN-1 (Caroni and Schwab, 1988a,b) and has been recently identified as Nogo (Chen et al., 2000). Treatment with IN-1 led to the promotion of axon regeneration both in vitro and in vivo (Schnell and Schwab, 1990; Weibel et al., 1994; Bregman et al., 1995; Thallmair et al., 1998). These studies give hope that CNS nerves may be coaxed into full functional regeneration in a clinical setting. However, only a small number of axons regenerate in these studies, in part because of other

Received Feb. 1, 2002; revised Jan. 15, 2003; accepted Jan. 24, 2003.

This work was supported by grants from the American Paralysis Association to D.G.J. and the National Institutes of Health to D.G.J. (EY11992 and NS34669) and M.H.J. (NS21725) and a National Research Service Award to E.V.W. We thank Russell McConnell, Catherine Linsenmayer, and the Tufts Vision Research Center for expert assistance with electron microscopy. We also thank Julie Kerner and Takashi Sakurai for helpful discussion and critical reading of this manuscript.

Correspondence should be addressed to Dr. Daniel G. Jay, Department of Physiology, Tufts University Medical School, 136 Harrison Avenue, MV709, Boston, MA 02111. E-mail: daniel.jay@tufts.edu.

Copyright $\odot 2003$ Society for Neuroscience $\quad$ 0270-6474/03/233112-06\$15.00/0 inhibitory proteins associated with myelin. One candidate for such a protein is myelin-associated glycoprotein (MAG).

MAG is a $\sim 100 \mathrm{kDa}$ transmembrane glycoprotein abundantly found in CNS myelin comprising $\sim 1 \%$ of total myelin protein (Quarles et al., 1973). Although also found in PNS myelin, it is 10 times more abundant in the CNS. MAG inhibits neurite outgrowth in cell culture (McKerracher et al., 1994; Mukhopadhyay et al., 1994), but its role in regeneration is controversial (David et al., 1995; Bartsch, 1996). It is present in a neurite outgrowthinhibitory fraction of CNS myelin, and a significant proportion of the inhibitory activity of myelin is removed by immunodepletion with anti-MAG antibodies (McKerracher et al., 1994). MAG causes growth cone collapse and inhibits neurite outgrowth from various vertebrate neuronal cell types, including retinal ganglion cells (RGCs) (McKerracher et al., 1994; Mukhopadhyay et al., 1994; Li et al., 1996; Song et al., 1998). However, the inhibitory activity of CNS myelin from MAG-deficient transgenic mice is not significantly diminished, and axon regeneration in the CNS of these MAG knock-out mice is improved only slightly (David et al., 1995) or not at all (Bartsch et al., 1995). In contrast to these studies, $\mathrm{MAG}^{-1-}$ mice cross-bred with $\mathrm{C} 57 \mathrm{BL} / \mathrm{Wld}{ }^{\mathrm{S}}$ showed improved PNS nerve regeneration in vivo (Schafer et al., 1996). When myelin proteins from $\mathrm{MAG}^{-1-}$ mice were separated by ion exchange chromatography, the fraction that should have contained MAG had markedly reduced inhibitory activity (David et al., 1995). The loss of inhibitory MAG activity may be compensated by expression of other myelin inhibitory proteins (depending on the genetic background). Thus, there is still no clear role 
for MAG in inhibiting nerve regeneration in the CNS in situ. Here we address this question by the acute inactivation of MAG in situ in chick retina-optic nerve cultures using chromophore-assisted laser inactivation (CALI).

\section{Materials and Methods}

Retinal strip cultures. Embryonic day 7 (E7) chick retinas were dissected away from the pigment epithelium and other tissue, flattened onto nitrocellulose filters, and cut into $400 \mu \mathrm{m}$ strips as described previously (Halfter et al., 1983). These retinal explant cultures extend long neurites from RGCs that form the optic nerve, a myelinated CNS nerve, in vivo. They were then cultured for $20 \mathrm{hr}$ at $37^{\circ} \mathrm{C}, 6 \% \mathrm{CO}_{2}$, in DMEM/F-12 (1:1) supplemented with $10 \%$ fetal bovine serum and $2 \%$ chick serum on 35 $\mathrm{mm}$ plastic dishes (Corning) or on acid-washed glass coverslips, coated with poly-L-lysine, fibronectin, or laminin. To test for growth cone collapse, a solution of soluble MAG $(10 \mu \mathrm{g} / \mathrm{ml})$ or myelin proteins $(0.5$ $\mathrm{mg} / \mathrm{ml}$ final) was added in the medium.

CALI of MAG/myelin in solution. For CALI treatment, myelin or MAG [both prepared as described previously (McKerracher et al., 1994)] was incubated for $60 \mathrm{~min}$ at room temperature with either the Malachite Green (MG)-labeled anti-MAG antibody, MG-3E4 (monoclonal prepared by S.D. against bovine myelin-associated glycoprotein), or the labeled anti-myelin proteolipid protein (PLP) antibody, MG-anti-PLP, (Calbiochem) at a final concentration of $200 \mathrm{ng} / \mathrm{ml}$. The solution was irradiated with an Nd:YAG laser (wavelength $620 \mathrm{~nm}$, total energy 45J) for $3 \mathrm{~min}$.

Retina-optic nerve organ culture. E15 retinas were explanted with attached optic nerve and tracts and given a crush injury with cold forceps halfway between the retina and the chiasm. Five microliters of MGlabeled antibody ( $2 \mathrm{mg} / \mathrm{ml}$ in HBSS) were injected into the optic nerve with a Hamilton syringe both proximal and distal to the lesion. These explants were incubated with MG-3E4 or MG-anti-PLP for $2 \mathrm{hr}$ at $37^{\circ} \mathrm{C}$, $6 \% \mathrm{CO}_{2}$, in the retina medium described in above, plus BDNF $(2 \mathrm{ng} / \mathrm{ml})$ for trophic support of the older explants (Rodriguez-Tebar et al., 1989). An area $\sim 3 \mathrm{~mm}$ in diameter was irradiated for $5 \mathrm{~min}$, and axons were anterograde-labeled with DiI crystals placed in the retina $>0.5 \mathrm{~mm}$ from optic fissure. The explant was incubated for $3 \mathrm{~d}$ to allow dye transport along the axons. For retrograde labeling, an FITC-dextran (fixable, 70 $\mathrm{kDa}$ ) flake or DiI crystal was placed on the nerve stump distal to the lesion, and the RGC cell bodies in the retinas were retrograde labeled only through axons that had regenerated past the lesion to the dye on the optic nerve stump. Observations were made and recorded with a Zeiss confocal microscope system.

CALI of MAG in explants. Retinas were cultured with their optic nerves still attached and extending to the optic chiasm. The optic nerves were injected with $5 \mathrm{ml}$ of either MG-3E4 or MG-anti-PLP (as a negative control). The optic nerve was then crushed with fine forceps midway between the retina and optic chiasm and incubated for $2 \mathrm{hr}$ at $37^{\circ} \mathrm{C}$ to allow the antibody to penetrate the tissue and bind. The optic nerve was laser irradiated within a $2-\mathrm{mm}$-diameter spot at the crush site. The explants were examined $36 \mathrm{hr}$ after CALI treatment. Enhanced axonal regeneration was demonstrated by anterograde DiI labeling of optic nerve fibers and by retrograde labeling of RGC cell bodies by DiI or FITCdextran at the distal optic nerve stump.

Light and electron microscopy. The presence of regenerated axons in the crush site after anti-MAG and anti-PLP antibody incubation and CALI was determined by light and electron microscopic analysis. Test and control optic nerves were fixed by immersion in $2 \%$ glutaraldehyde and freshly prepared 2\% paraformaldehyde in Dulbecco's PBS, pH 7.4, for 3 $\mathrm{hr}$ at room temperature followed by the same fix overnight at $4^{\circ} \mathrm{C}$. The tissue was rinsed once in PBS and then postfixed for $2 \mathrm{hr}$ at room temperature in $1 \%$ osmium tetroxide reduced with $1 \%$ potassium ferricyanide in $0.1 \mathrm{M}$ sodium cacodylate buffer containing $5 \%$ sucrose. The tissue was then rinsed briefly in distilled water, dehydrated in a graded series of ethanols, and embedded in Embed 812 (Jacob et al., 1986; Williams et al., 1998). Thick sections ( $1 \mu \mathrm{m})$ were stained with toluidine blue, mounted in Permount, and viewed by bright-field microscopy with a Zeiss Axioskop microscope. For ultrastructural analysis, thin sections were stained with 5\% aqueous uranyl acetate and viewed with a Philips CM10 electron microscope.

Chondroitin sulfate proteoglycan immunohistochemistry. Optic nerves were fixed in $4 \%$ paraformaldehyde in $100 \mathrm{~mm}$ phosphate buffer and gradually equilibrated to $30 \%$ sucrose. The nerves were embedded and frozen in Tissue-Tek and cut into $15 \mu \mathrm{m}$ sections on a cryostat. Chondroitin sulfate proteoglycan (CSPG) immunohistochemistry was performed with antibody 9BA12 (a generous gift from W. Halfter, University of Pittsburgh) and Alexa-Fluor-conjugated secondary antibody (Molecular Probes) by epifluorescence with a Nikon T200 microscope and a Micromax YHS-1300 CCD camera.
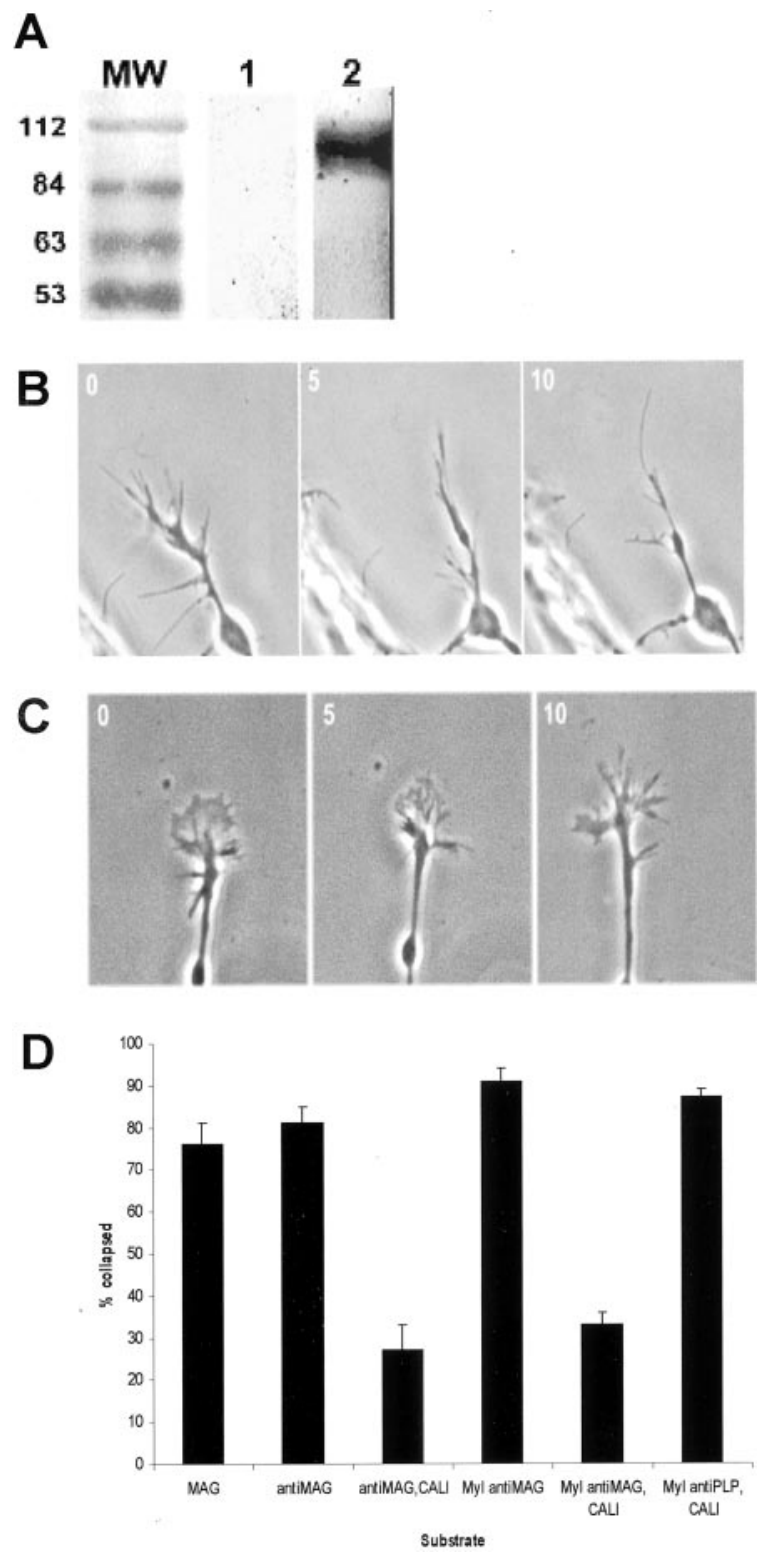

Figure 1. Retinal ganglion cell growth cones collapse in response to CNS myelin or recombinant MAG. $A$, Western blot of chick brain myelin with 3E4. Lane 1 is a no primary antibody control; lane 2 is probed with the $3 \mathrm{E} 4$ antibody and displays a prominent band of MAG at 110 $\mathrm{kDa}$. B, An RGC growth cone on fibronectin is shown collapsing in response to $\mathrm{MAG}(0.5 \mathrm{mg} / \mathrm{ml})$. C, MAG inactivated by CALI does not cause growth cone collapse. D, Retinal explants grown on bronectin were assayed with MAG (MAG), MAG inactivated by CALI (antiMAG), MAG treated with 3 E4 but without laser (antiMAG,CALI), myelin treated with 3E4 without laser (Myl antiMAG), myelin treated with CALI against MAG(Myl antiMAG,CALI), and myelin treated with CALl against myelin proteolipid protein (Myl antiPLP, CALI). Error bars reflect SE. CALI of MAG and control treatment results are significantly different as measured by unpaired $t$ test $(p<0.0001)$. 


\section{Results}

We investigated the contribution of MAG to the inhibitory properties of myelin in axon regeneration in the CNS. To do this, we acutely inactivated MAG in CNS myelin using CALI (Jay, 1988) in retina-optic nerve organotypic cultures. CALI inactivates a protein of interest by targeting laser energy using a specific antibody labeled with the dye Malachite Green. After laser irradiation with $620 \mathrm{~nm}$ light, the excited MG releases short-lived free radicals to inactivate proteins bound by the antibody (half-maximal inactivation radius 15A) (Liao et al., 1994). CALI selectively inactivates MAG at the time and location of irradiation. In the case of nerve crush, this allows us to assess the function of MAG without compensatory changes in other inhibitory proteins.

For CALI of MAG, we used a monoclonal antibody, INM2C4.3E4 (3E4), which recognizes an extracellular epitope of MAG (data not shown). 3E4 was generated against bovine myelin and crossreacts specifically with MAG in chick CNS myelin preparations (Fig. 1A). We tested CALI of MAG on E7 chick retinal explants grown on fibronectin because we observed that MAG caused $\sim 80 \%$ of the RGC growth cones to collapse for explants grown on fibronectin but not on laminin, in agreement with published studies (David et al., 1995). After the explants had extended long neurites, they were treated with MAG or myelin in solution at 0.5 $\mathrm{mg} / \mathrm{ml}$. Figure $1 B$ shows that MAG collapses retinal growth cones. CALI of MAG prevents this collapse (Fig. 1C). Figure $1 D$ summarizes experiments using both recombinant MAG and CNS myelin. Both MAG and myelin effectively collapse RGCs in this preparation, causing 80-90\% collapse, and adding MG-antiMAG to either of these preparations does not block collapse by itself. In contrast, CALI of MAG (MG-anti-MAG + laser irradiation) caused significant reduction in the extent of collapse such that only $20-30 \%$ of the growth cones collapsed. CALI directed against myelin PLP, another abundant myelin component expressed in a pattern similar to MAG in the E15 optic nerve (data not shown), does not affect the ability of myelin to collapse growth cones. These findings show that CALI of MAG is effective and specific and that this approach may be used to test the role of MAG in CNS nerve regeneration in situ.

We applied CALI of MAG to regions of nerve crush in E15 chick optic nerve organotypic cultures to address the in situ role of MAG in regeneration. At E15, optic nerve myelination in chick has just begun, and MAG-immunoreactive oligodendrocytes can be observed throughout the optic tract (data not shown). Retinas were cultured with their optic nerves still attached and extending to the optic chiasm. These explants were injected with either
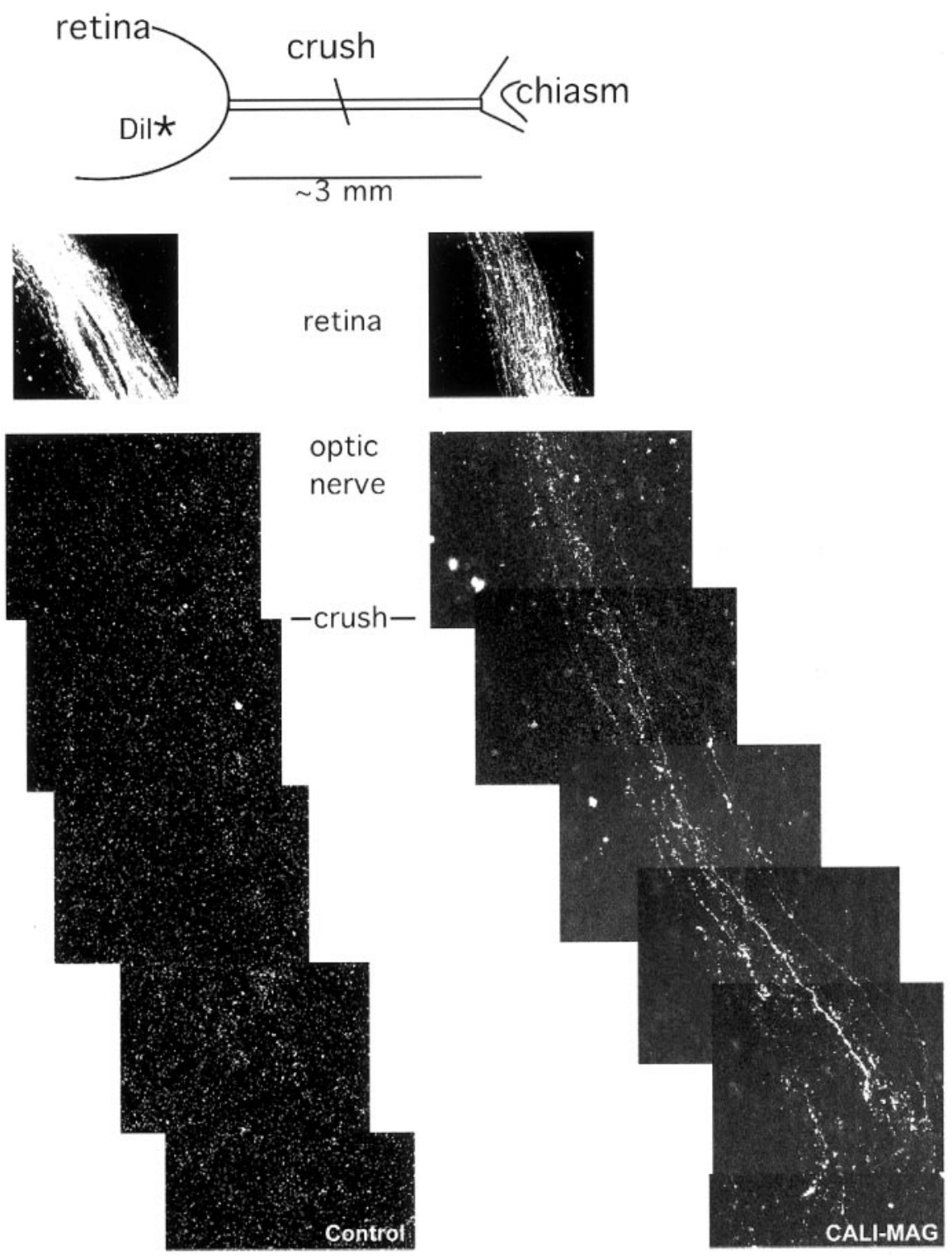

Figure 2. CALI of MAG enhances regeneration in E15 optic nerve. E15 retinas were explanted with attached optic nerve and tracts and given a crush injury with cold forceps halfway between the retina and chiasm. The axons were anterograde labeled with Dil crystals placed in the retina $>0.5 \mathrm{~mm}$ from the optic fissure. As the explant was incubated for $3 \mathrm{~d}$, the dye was transported up axons, and in the case of CALI-MAG (right panels), these axons could be seen beyond the point of lesion. In contrast, the control explant treated with CALI-PLP (left panels) showed no axon labeling beyond the lesion. Scale bar, $20 \mu \mathrm{m}$.

MG-3E4 or MG-anti-PLP (as a negative control) immediately before the optic nerve was crushed midway between the retina and optic chiasm. After a $2 \mathrm{hr}$ incubation at $37^{\circ} \mathrm{C}$ to allow antibodies to penetrate the tissue and bind MAG or PLP, the optic nerve was laser irradiated within a $2 \mathrm{~mm}$ spot at the crush site. The laser spot did not encompass the entire nerve; rather, it left 1-2 mm on either side of the spot untreated. Axonal regeneration was assessed by anterograde labeling from the retina with DiI. In CALI of PLP-treated explants, we did not observe labeled axons along the optic nerve, despite bright fluorescence seen in the retina (Fig. 2, left panels). In contrast, fluorescent axons were observed throughout the optic nerve beyond the crush site in the CALI of MAG-treated tissue (Fig. 2, right panels). Regenerating axons in the MAG-inactivated explants grew to the end of the explant within $36 \mathrm{hr}$. This growth was at least $2 \mathrm{~mm}$ beyond the crush site and was the farthest extent possible in these experi- 


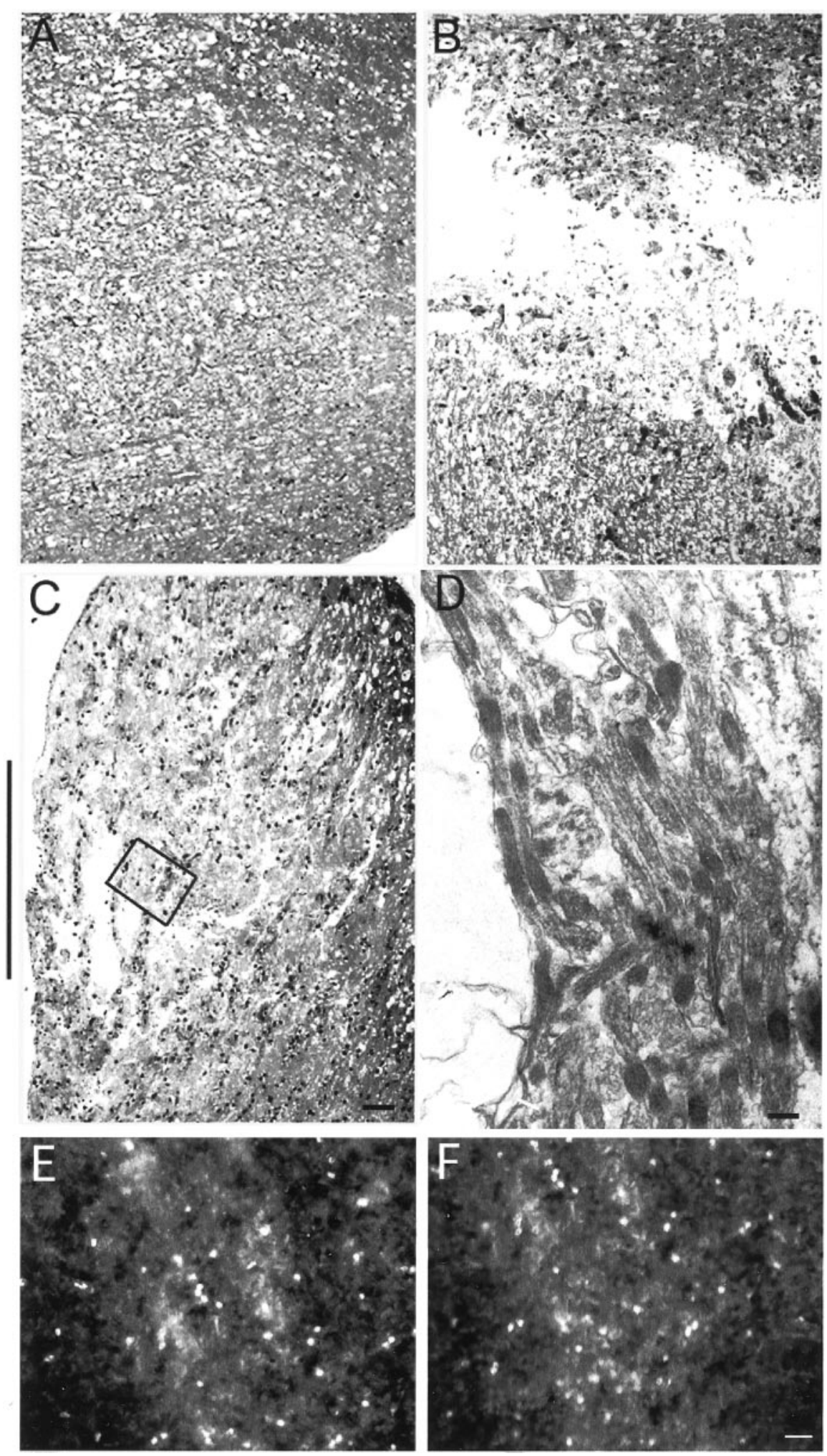

Figure 3. Histology of crush site. Light and electron micrographs demonstrating the histological appearance of the optic nerve crush site in test and control conditions. A, Control optic nerve shows the normal intact axons. B, Crushed optic nerve treated with anti-PLP antibody and CALI shows the site of damage and absence of axons that cross the gap. C, Crushed optic nerve treated with anti-MAG antibody and CALI shows the site of the crush that is now occupied mostly by regenerated axon processes, with only small regions of damage remaining. Scale bar, $24 \mu \mathrm{m}$. Black side bars show the site of nerve crush in $B$ and $C$. Thin unmyelinated regenerating axons were confirmed at part of this site of nerve crush (marked by black box in C) after CALI of MAG using electron microscopy (D). Magnification, 34,000×. Scale bar, $0.14 \mu \mathrm{m}$. CSPG immunohistochemistry of the optic nerve crush site in anti-PLP-treated $(E)$ and anti-MAG-treated $(F)$ tissue shows no differences between the two treatments. Scale bar, $30 \mu \mathrm{m}$. ments. Ultrastructural photomicrographs (Fig. $3 A-C$ ) also show that fibers extend across the lesion site in the CALI of MAGtreated optic nerve (Fig. 3C) but not across the crush site in the CALI of PLP control (Fig. 3B). Electron microscopy of the site of nerve crush in the CALI of MAG-treated optic nerve shows many intact regenerating axons (Fig. 3D). Furthermore, CALI of MAG did not significantly alter the expression of at least one other inhibitory molecule found in the chick optic nerve, chondroitin sulfate proteoglycan (Fig. 3E,F). The spotty staining pattern seen in both control and CALI of MAG-treated optic nerve is expected, because myelination is only in initial stages at this age. Together, these findings support the hypothesis that the direct localized loss of MAG function allows for significant axon regrowth across a site of nerve crush.

We quantified the extent of axonal regeneration by placing DiI crystals at the cut end of the optic nerve $36 \mathrm{hr}$ after CALI and assessing fluorescent labeling in the retina. The fluorescently labeled RGC soma in the retina were counted $24 \mathrm{hr}$ later $(n>10$ retinas for each experimental treatment). Figure $4 A$ shows retrogradely labeled retinal cells of E15 retina-optic nerve explants immediately after removal from the embryo, without crush or CALI treatment (98 \pm 13 soma per square millimeter). When retrograde labeling was performed after a crush lesion, fluorescent cells or axons in the retina were never observed (Fig. 4B), reflecting the lack of regenerated fibers distal to the site of lesion. In contrast, CALI of MAG resulted in marked retinal axon regeneration as measured by the number of fluorescent cell bodies ( $89 \pm 16$ soma per square millimeter) (Fig. 4D). None of the control treatments promoted regeneration. CALI directed against PLP had no effect on regeneration because no labeled retinal cells were seen (Fig. 4C). Similarly, neither laser irradiation alone nor MG-3E4 antibody without irradiation promoted regeneration into the E15 optic nerve. Our findings are summarized in Figure $4 E$. These observations demonstrate a significant inhibitory role for MAG in optic nerve growth in situ and that inactivation of MAG in a myelinated CNS nerve allows axon regeneration into this previously inhibitory environment.

\section{Discussion}

Our findings establish that MAG is a prominent contributor to the inhibition of CNS nerve regeneration in situ. We 


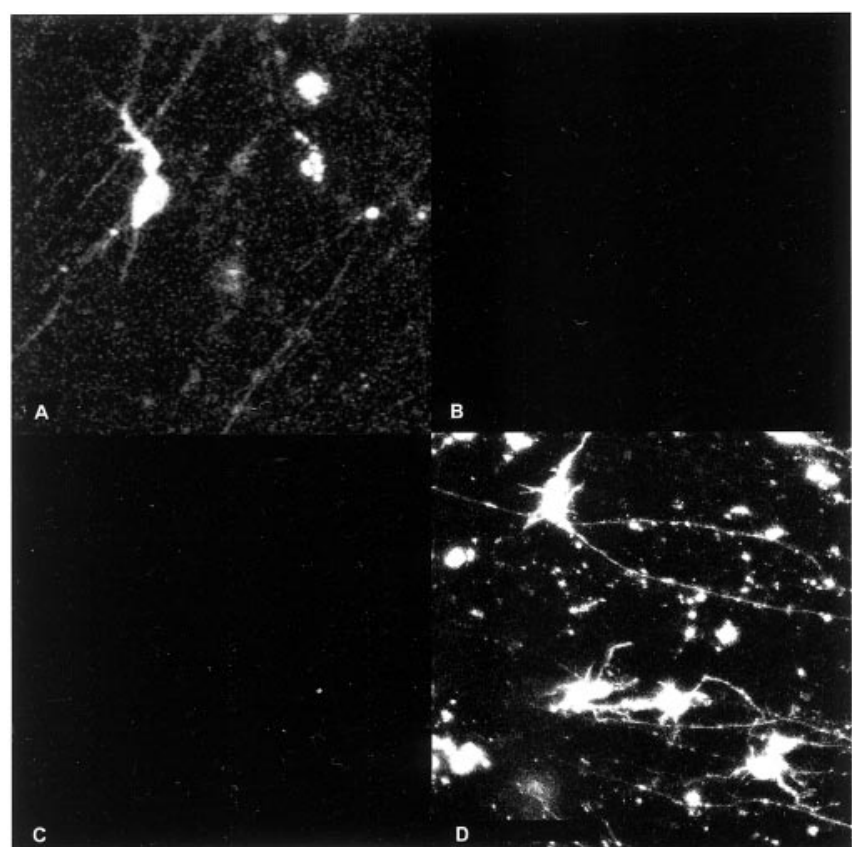

E

\begin{tabular}{|l|c|}
\hline Treatment & Fluorescent cells $/ \mathrm{mm}^{2}$ \\
\hline No crush & $98 \pm 13^{*}$ \\
\hline Crush & $0 \pm 0$ \\
\hline Crush with CALI-no Ab & $0 \pm 0$ \\
\hline Crush with CALI-PLP & $0 \pm 0$ \\
\hline Crush with CALI-MAG & $89 \pm 16^{*}$ \\
\hline
\end{tabular}

*S.E.M.

Figure 4. CALI of MAG permits regeneration of myelinated optic nerve. E15 retinas from retina- optic nerve explants retrogradely labeled with Di0 are shown. Representative fields are shown for E15 no crush $(A)$, E15 crush (B), E15 with PLP inactivation ( $C$, and E15 with MAG inactivation $(D)$. Scale bar, $10 \mu \mathrm{m}$. E, Quantification of the retrograde-labeled soma was performed in the three brightest $0.2 \mathrm{~mm}^{2}$ camera fields per retina $(n=10)$, and the average label density and SE are given for each condition. Pictures were taken at identical brightness/contrast settings on a Zeiss confocal microscope. no Ab, No antibody.

used an organotypic culture system that models regeneration of the optic nerve after crush injury. Under normal culture conditions, neither anterograde nor retrograde labeling can detect axons that cross the lesion. However, after specific inactivation of MAG, axons are clearly seen crossing the crush site, and retrograde labeling from the nerve stump labels retinal soma to the same extent seen with explants that were not crushed. The lack of regeneration after CALI of PLP, another abundant myelin protein, argues against nonspecific damage to myelin as a cause of the observed regeneration. Although it is possible that CALI could inactivate neighboring proteins that may be inhibitory, our previous work has shown a high degree of spatial restriction of CALImediated damage, even within a multi-subunit membrane protein in situ (Liao et al., 1995). Thus, collateral inactivation of nearest neighbors is unlikely. Unintended disruption of the optic nerve by the CALI of MAG treatment was also investigated microscopically and immunohistochemically. We assessed immunoreactivity to antibodies against myelin proteolipid protein and a carbohydrate epitope of CSPGs. There was no significant difference in the staining pattern of either antigen.
Although in vitro studies have implicated MAG as an inhibitor of neurite outgrowth (McKerracher et al., 1994; Mukhopadhyay et al., 1994), genetic knock-out experiments have not provided a clear role for MAG in CNS regeneration. In experiments in which neurons were grown on sections of CNS white matter from MAG-deficient and wild-type mice, there was no significant difference between the two substrates (Bartsch et al., 1995). However, compensatory mechanisms may have upregulated expression of other inhibitory myelin components, such as the Nogo proteins. In fact, there is precedent for genetic compensation after knock-out of two myelin genes encoding $\mathrm{P}_{0}$ and myelin basic protein (Martini et al., 1995).

It is curious that CALI of MAG allowed significant regrowth of axons through CNS myelin despite the presence of other inhibitory activities (such as Nogo). Our findings do not discount the importance of other inhibitory factors in the myelin that may also act on the neurons. Indeed, chromatographic separation of myelin proteins has revealed several fractions with outgrowth inhibitory activity (McKerracher et al., 1994). Although we did not assay directly for changes in activity of other inhibitory molecules, immunohistochemistry suggests that at least the expression pattern of such inhibitory molecules as CSPGs is not significantly disturbed by the CALI treatment. Furthermore, the in vitro experiments support the selective inactivation of MAG, rather than altered expression of other inhibitory molecules, as the factor encouraging neurite outgrowth. We suggest that the loss of MAG acutely disrupts the balance between inhibitory and growthpromoting factors in myelin so that outgrowth is favored. For example, it is thought that laminin (a permissive substrate) in the PNS can override the inhibitory effects of MAG such that PNS nerve regeneration is possible despite the presence of MAG (David et al., 1995). However, the balance of positive and negative cues in nerve regeneration are likely to be complex. The repulsive activity of MAG can be converted into attraction by elevating intracellular cAMP (Song et al., 1998) or priming neurons with neurotrophins (Ming et al., 1999).

Many studies using the IN-I blocking antibody have demonstrated the role of Nogo in preventing regeneration (Schnell and Schwab, 1990; Weibel et al., 1994; Bregman et al., 1995; Thallmair et al., 1998). However, only limited regeneration has been observed after treatment with IN-1 (Bregman et al., 1995; Thallmair et al., 1998). Thus it would be interesting to inactivate MAG and Nogo simultaneously and assess regeneration after injury in myelinated CNS tissues such as optic nerve or spinal cord. Previous studies have combined IN-1 application with other potential therapies (Guest et al., 1997) such as localized application of fibroblast growth factor or neurotrophins (Cheng et al., 1996). CALI of MAG could also be combined with these treatments. The laser irradiation used for CALI does not damage tissue nonspecifically, and the turnover time of myelin proteins in mammals is $>1$ month (Toews et al., 1988). Thus there is the potential for a local prolonged absence of MAG at the site of injury such that axon outgrowth across the site could occur. Because the antibody and laser are applied locally and acutely during CALI, potential adverse effects of chronic antibody application are reduced. It has been shown that chronic application of function-blocking antibody against MAG can cause demyelination of mouse optic nerve (Sergott et al., 1988), and systemic loss of MAG by autoimmune responses has been linked to neuropathies such as multiple sclerosis (Quarles, 1989). As such, a CALI-based therapy directed against MAG may potentially lend itself to clinical use. 


\section{References}

Bartsch U (1996) Myelination and axonal regeneration in the central nervous system of mice deficient in the myelin-associated glycoprotein. J Neurocytol 25:303-313.

Bartsch U, Bandtlow CE, Schnell L, Bartsch S, Spillmann AA, Rubin BP, Hillenbrand R, Montag D, Schwab ME, Schachner M (1995) Lack of evidence that myelin-associated glycoprotein is a major inhibitor of axonal regeneration in the CNS. Neuron 15:1375-1381.

Bregman BS, Kunkel-Bagden E, Schnell L, Dai HN, Gao D, Schwab ME (1995) Recovery from spinal cord injury mediated by antibodies to neurite growth inhibitors. Nature 378:498-501.

Caroni P, Schwab ME (1988a) Two membrane protein fractions from rat central myelin with inhibitory properties for neurite growth and fibroblast spreading. J Cell Biol 106:1281-1288.

Caroni P, Schwab ME (1988b) Antibody against myelin-associated inhibitor of neurite growth neutralizes nonpermissive substrate properties of CNS white matter. Neuron 1:85-96.

Chen MS, Huber AB, van der Haar ME, Frank M, Schnell L, Spillmann AA, Christ F, Schwab ME (2000) Nogo-A is a myelin-associated neurite outgrowth inhibitor and an antigen for monoclonal antibody IN-1. Nature 403:434-439.

Cheng H, Cao Y, Olson L (1996) Spinal cord repair in adult paraplegic rats: partial restoration of hind limb function. Science 273:510-513.

David S, Aguayo AJ (1981) Axonal elongation into peripheral nervous system "bridges" after central nervous system injury in adult rats. Science 214:931-933.

David S, Braun PE, Jackson DL, Kottis V, McKerracher L (1995) Laminin overrides the inhibitory effects of peripheral nervous system and central nervous system myelin-derived inhibitors of neurite growth. J Neurosci Res 42:594-602.

Guest JD, Hesse D, Schnell L, Schwab ME, Bunge MB, Bunge RP (1997) Influence of IN-1 antibody and acidic FGF-fibrin glue on the response of injured corticospinal tract axons to human Schwann cell grafts. J Neurosci Res 50:888-905.

Halfter W, Newgreen DF, Sauter J, Schwarz U (1983) Oriented axon outgrowth from avian embryonic retinae in culture. Dev Biol 95:56-64.

Jacob MH, Lindstrom JM, Berg DK (1986) Surface and intracellular distribution of a putative neuronal nicotinic acetylcholine receptor. J Cell Biol 103:205-214.

Jay DG (1988) Selective destruction of protein function by chromophoreassisted laser inactivation. Proc Natl Acad Sci USA 85:5454-5458.

Li M, Shibata A, Li C, Braun PE, McKerracher L, Roder J, Kater SB, David S (1996) Myelin-associated glycoprotein inhibits neurite/axon growth and causes growth cone collapse. J Neurosci Res 46:404-414.

Liao JC, Roider J, Jay DG (1994) Chromophore-assisted laser inactivation of proteins is mediated by the photogeneration of free radicals. Proc Natl Acad Sci USA 91:2659-2663.

Liao JC, Berg LJ, Jay DG (1995) Chromophore-assisted laser inactivation of subunits of the T-cell receptor in living cells is spatially restricted. Photochem Photobiol 62:923-929.

Martini R, Mohajeri MH, Kasper S, Giese KP, Schachner M (1995) Mice doubly deficient in the genes for $\mathrm{PO}$ and myelin basic protein show that both proteins contribute to the formation of the major dense line in peripheral-nerve myelin. J Neurosci 15:4488-4495.

McKerracher L, David S, Jackson DL, Kottis V, Dunn RJ, Braun PE (1994) Identification of myelin-associated glycoprotein as a major myelinderived inhibitor of neurite growth. Neuron 13:805-811.

Ming G, Song H, Berninger B, Inagaki N, Tessier-Lavigne M, Poo M (1999) Phospholipase C-gamma and phosphoinositide 3-kinase mediate cytoplasmic signaling in nerve growth cone guidance. Neuron 23:139-148.

Mukhopadhyay G, Doherty P, Walsh FS, Crocker PR, Filbin MT (1994) A novel role for myelin-associated glycoprotein as an inhibitor of axonal regeneration. Neuron 13:757-767.

Quarles RH (1989) Myelin-associated glycoprotein in demyelinating disorders. Crit Rev Neurobiol 5:1-28.

Quarles RH, Everly JL, Brady RO (1973) Evidence for the close association of a glycoprotein with myelin in rat brain. J Neurochem 21:1177-1191.

Rodriguez-Tebar A, Jeffrey PL, Thoenen H, Barde YA (1989) The survival of chick retinal ganglion cells in response to brain-derived neurotrophic factor depends on their embryonic age. Dev Biol 136:296-303.

Schafer M, Fruttiger M, Montag D, Schachner M, Martini R (1996) Disruption of the gene for the myelin-associated glycoprotein improves axonal regrowth along myelin in C57BL/Wlds mice. Neuron 16:1107-1113.

Schnell L, Schwab ME (1990) Axonal regeneration in the rat spinal cord produced by an antibody against myelin-associated neurite growth inhibitors. Nature 343:269-272.

Sergott RC, Brown MJ, Lisak RP, Miller SL (1988) Antibody to myelinassociated glycoprotein produces central nervous system demyelination. Neurology 38:422-426.

Song H, Ming G, He Z, Lehmann M, McKerracher L, Tessier-Lavigne M, Poo M (1998) Conversion of neuronal growth cone responses from repulsion to attraction by cyclic nucleotides. Science 281:1515-1518.

Thallmair M, Metz GA, Z'Graggen WJ, Raineteau O, Kartje GL, Schwab ME (1998) Neurite growth inhibitors restrict plasticity and functional recovery following corticospinal tract lesions. Nat Neurosci 1:124-131.

Toews AD, White FV, Morell P (1988) Metabolism of functional groups modifying the CNS myelin-associated glycoprotein. J Neurochem 51:1646-1650.

Weibel D, Cadelli D, Schwab ME (1994) Regeneration of lesioned rat optic nerve fibers is improved after neutralization of myelin-associated neurite growth inhibitors. Brain Res 642:259-266.

Williams B, Temburni MK, Levey M, Bertrand D, Bertrand S, Jacob MH (1998) The long internal loop of the $\alpha 3$ subunit targets nAChRs to subdomains within individual synapses on neurons in vivo. Nat Neurosci 1:557-562. 